\title{
Perencanaan Prototipe Sistem Informasi Pariwisata Berbasis Web Di Kabupaten Dairi Sumatera Utara
}

\author{
Dewi Yanti \\ Politeknik Pariwisata Medan \\ E-mail : dewie.yanthi@gmail.com
}

\begin{abstract}
Dairi is one of the districts located in the area of Lake Toba which has considerable tourism potential. The development of information technology currently plays an important role. With the help of technology, many things become easier, one of which is the delivery of information. This study aims to design a prototype web-based tourism information system in Dairi so that tourists is more easily in obtaining tourism information. The method used in this research is descriptive because this research analyzes and presents facts systematically so it can be easier to conclude. Data collection was done by distributing questionnaires and observations. The design of the system prototype in this study includes the design of Data Flow Diagrams, Flowchart, Database Design, and Output Design. The result of the prototype of tourism information system in Dairi covers various information about tourism in Dairi such as Dairi history, cultural art, custom and culture of Batak, cultural heritage, arts and crafts, art community, transportation to tourism object, tourism map, calendar of events, facilities in tourist attraction, nature tourism, shopping tourism, religious tourism, culinary tourism, cultural tourism, and other information.
\end{abstract}

Keywords: Prototype, Information System, Tourism

\begin{abstract}
Abstrak - Kabupaten Dairi merupakan salah satu kabupaten yang berada di kawasan Danau Toba yang memiliki potensi pariwisata cukup besar. Perkembangan teknologi informasi saat ini memegang peranan penting. Dengan bantuan teknologi, banyak hal yang dijadikan menjadi lebih mudah, salah satunya penyampaian informasi. Penelitian ini bertujuan untuk merancang prototipe sistem informasi pariwisata berbasis web di Kabupaten Dairi agar wisatawan lebih mudah dalam memperoleh informasi pariwisata. Metode yang digunakan pada penelitian ini adalah deskriptif karena penelitian ini menganalisa dan menyajikan fakta secara sistematis sehingga dapat lebih mudah untuk disimpulkan. Pengumpulan data dilakukan dengan cara menyebarkan kuesioner dan observasi. Perancangan prototipe sistem pada penelitian ini diantaranya perancangan Data Flow Diagram, Flowchart, Perancangan Database, serta Perancangan Output. Hasil protipe sistem informasi pariwisata di Kabupaten Dairi meliputi berbagai informasi tentang pariwisata yang ada di Kabupaten Dairi seperti sejarah Dairi, seni budaya, adat dan budaya Batak, cagar budaya, seni dan kerajinan, komunitas seni, transportasi menuju objek wisata, peta pariwisata, calendar of event, fasilitas di objek wisata, wisata alam, wisata belanja, wisata religi, wisata kuliner, wisata budaya, dan informasi lainnya.
\end{abstract}

Kata Kunci : Prototipe, Sistem Informasi, Pariwisata

\subsection{Latar Belakang}

Perkembangan pariwisata di Indonesia mengalami peningkatan yang cukup signifikan. Peningkatan tersebut dilihat dari jumlah wisatawan mancanegara yang mengunjungi Indonesia semakin meningkat dari tahun ke tahun. Sektor pariwisata di Indonesia telah menjadi salah satu program prioritas pemerintah yang harus ditingkatkan karena pariwisata akan membawa dampak yang signifikan terhadap perekonomian. Hal ini disebabkan pariwisata mempunyai peran yang sangat penting dalam pembangunan Indonesia khususnya sebagai penghasil devisa negara di samping sektor migas.

Sumatera Utara yang merupakan salah satu Provinsi di Indonesia memiliki beragam tempat wisata yang menarik dan banyak dikunjungi oleh wisatawan. Provinsi ini memiliki banyak potensi wisata seperti: panorama dan keindahan alam di daerah tujuan wisata yang tersebar di 
berbagai daerah kabupaten. Dilihat dari objek dan daya tarik, wisata alam memiliki potensi yang sangat bagus untuk dikembangkan dan dapat berperan penting dalam meningkatkan pariwisata di Sumatera Utara.

Salah satu potensi wisata yang ada di Sumatera Utara adalah di Kabupaten Dairi. Kabupaten Dairi memiliki potensial pariwisata yang sangat menarik untuk ditelusuri. Keindahan alam yang khas yang masih terpelihara menjadikannya sebagai salah satu pariwisata yang memiliki daya tarik tersendiri, namun sayangnya saat ini tempat pariwisata yang ada di Kabupaten Dairi masih belum terpublikasi karena ada beberapa tempat yang letaknya berada jauh di daerah pelosok sehingga penyampaian informasi masih sangat terbatas. Pengemasan informasi sangat diperlukan karena merupakan salah satu upaya mempercepat penyampaian dan pemanfaatan informasi.

Sistem informasi merupakan sarana alternatif untuk membantu memberikan informasi bagi suatu lembaga/perusahaan ataupun perorangan. Salah satunya adalah website, merupakan sarana promosi yang memberikan kemudahan bagi siapa saja yang ingin mengaksesnya kapanpun dan dimanapun. Maka dari itu diperlukan suatu perencanaan sistem informasi pariwisata daerah Kabupaten Dairi berbasis web untuk menarik wisatawan lokal maupun wisatawan asing untuk berwisata ke Kabupaten Dairi. Semakin banyak wisatawan yang berkunjung maka pendapatan daerah dan masyarakat sekitarnya akan mengalami peningkatan. Selain itu dengan adanya sistem informasi pariwisata berbasis Web maka objek-objek wisata di daerah Kabupaten Dairi akan lebih di kenal oleh masyarakat luas serta memotivasi bagi pemerintah setempat untuk lebih memperhatikan pengelolaan pada tempattempat pariwisata tersebut. Berdasarkan latar belakang tersebut maka penulis tertarik untuk melakukan penelitian dengan judul "Perencanaan Prototipe Sistem Informasi Pariwisata Berbasis Web di Kabupaten Dairi Sumatera Utara". Adapun tujuan penelitian ini adalah untuk merancang prototipe sistem informasi pariwisata berbasis web yang diharapkan oleh wisatawan dalam memperoleh informasi pariwisata di kabupaten Dairi.

\subsection{Tinjauan Pustaka}

2.1.1. Konsep Dasar Sistem Informasi Terdapat berbagai macam pengertian sistem informasi menurut para ahli, diantaranya sebagai berikut :

Menurut Nugroho (2011:128) Sistem informasi adalah sebuah sistem yang mempunyai fungsi mengumpulkan, memproses, menyimpan, menganalisis, dan menyebarkan informasi untuk tujuan yang spesifik.

Menurut Sutabri (2012:46) Sistem informasi adalah suatu sistem di dalam suatu organisasi yang mempertemukan kebutuhan pengolahan transaksi harian yang mendukung fungsi operasi organisasi yang bersifat manajerial dengan kegiatan strategi dari suatu organisasi untuk dapat menyediakan kepada pihak luar tertentu dengan laporan-laporan yang diperlukan.

Berdasarkan beberapa pengertian sistem informasi yang dikemukakan oleh para ahli di atas dapat disimpulkan bahwa sistem informasi adalah sebuah sistem yang terdiri dari pengumpulan, pemasukan, pemrosesan data, penyimpanan, pengolahan, pengendalian dan pelaporan sehingga tercapai sebuah informasi yang mendukung pengambilan keputusan didalam suatu organisasi untuk dapat mencapai sasaran dan tujuannya.

\subsubsection{Komponen Sistem Informasi}

Sistem informasi terdiri dari lima sumber daya yang dikenal sebagai komponen sistem informasi. Kelima sumber daya tersebut adalah manusia, hardware, software, data, dan jaringan. Kelima komponen tersebut memainkan peranan yang sangat penting dalam suatu sistem informasi. Namun dalam kenyataannya, tidak semua sistem informasi mencakup kelima komponen tersebut (Mulyanto, $2010: 31$ ).

Berikut merupakan penjelasan komponen dari sistem informasi :

1. Sumber Daya Manusia. Manusia mengambil peranan yang penting bagi sistem informasi. Manusia dibutuhkan untuk mengoperasikan sistem informasi. Sumber daya manusia dapat 
dibedakan menjadi dua kelompok yaitu pengguna akhir dan pakar sistem informasi. Pengguna akhir adalah orang-orang yang menggunakan informasi yang dihasilkan dari sistem informasi, sedangkan pakar sistem informasi orang-orang yang mengembangkan dan mengoperasikan sistem informasi.

2. Sumber Daya Hardware. Sumber daya hardware adalah semua peralatan yang digunakan dalam pemrosesan informasi. Sumber daya ini tidak hanya sebatas komputer saja, melainkan semua media data seperti lembaran kertas dan disk magnetik atau optikal.

3. Sumber Daya Software. Sumber daya software adalah semua rangkaian perintah (instruksi) yang digunakan untuk memproses informasi. Sumber daya ini tidak hanya berupa program saja, tetapi juga berupa prosedur.

4. Sumber Daya Data. Sumber daya data bukan hanya sekedar bahan baku untuk memasukan sebuah sistem informasi, melainkan sebagai dasar membentuk sumber daya organisasi.

5. Sumber Daya Jaringan. Sumber daya jaringan merupakan media komunikasi yang menghubungkan komputer, memproses komunikasi, dan peralatan lainnya, serta dikendalikan melalui software komunikasi. Sumber daya ini dapat berupa media komunikasi seperti kabel, satelit dan dukungan jaringan seperti modem, software pengendali, serta prosesor antar jaringan.

\subsubsection{Klasifikasi Sistem Informasi}

Sistem informasi dapat dibentuk sesuai kebutuhan organisasi masingmasing. Oleh karena itu, untuk dapat menerapkan sistem yang efektif dan efisien diperlukan perencanaan, pelaksanaan, pengaturan, dan evaluasi sesuai keinginan masing-masing organisasi. Klasifikasi sistem informasi tersebut sebagai berikut :

1. Sistem informasi berdasarkan level organisasi

Dikelompokkan menjadi level operasional, level fungsional dan level manajerial.

2. Sistem informasi berdasarkan aktifitas manajemen
Dikelompokkan menjadi sistem informasi perbankan, sistem informasi akademik, sistem informasi kesehatan, sistem informasi asuransi dan sistem informasi perhotelan.

3. Sistem informasi berdasarkan fungsionalitas bisnis

Dikelompokkan menjadi sistem informasi akuntansi, sistem informasi keuangan, sistem informasi manufaktur, sistem informasi pemasaran dan sistem informasi sumber daya manusia.

\subsubsection{Tujuan Sistem Informasi}

Menurut Mustakini (2010:13) tujuan

dari sistem informasi adalah menghasilkan informasi (Information) dari bentuk data yang diolah menjadi bentuk yang berguna bagi para pemakainya. Tujuan sistem informasi terdiri dari Kegunaan (Usefulness), Ekonomi (Economic), Keandalan (Realibility), Pelayanan Langganan (Customer Service), Kesederhanaan (Simplicity), dan Fleksibilitas (Fleksibility).

1. Kegunaan (Usefulness). Sistem harus menghasilkan informasi yang akurat, tepat waktu, dan relevan untuk pengambilan keputusan manajemen dan personil operasi di dalam organisasi.

2. Ekonomi (Economic). Semua bagian komponen sistem termasuk laporanlaporan, pengendalian-pengendalian, mesin-mesin harus menyumbang suatu nilai manfaat setidak-tidaknya sebesar biaya yang dibutuhkan.

3. Keandalan (Realibility). Keluaran sistem harus mempunyai tingkatan ketelitian yang tinggi dan sistem itu sendiri harus mampu beroperasi secara efektif bahkan pada waktu komponen manusia tidak hadir atau saat komponen mesin tidak beroperasi secara temporer.

4. Pelayanan Langganan (Customer Service). Sistem harus memberikan pelayanan dengan baik atau ramah kepada para pelanggan. Sehingga sistem tersebut dapat diminati oleh para pelanggannya.

5. Kesederhanaan (Simplicity). Sistem harus cukup sederhana sehingga terstruktur dan operasinya dapat 
dengan mudah dimengerti dan prosedurnya mudah diikuti.

6. Fleksibilitas (Fleksibility). Sistem harus cukup fleksibel untuk menangani perubahan-perubahan yang terjadi, kepentingannya cukup beralasan dalam kondisi dimana sistem beroperasi atau dalam kebutuhan yang diwajibkan oleh organisasi.

\subsubsection{Sistem Informasi Pariwisata}

Merujuk pada pengertian sistem informasi, yakni sekumpulan komponenkomponen yang saling berhubungan dan bekerjasama untuk mengumpulkan, memproses, menyimpan dan mendistribusikan informasi terkait untuk mendukung proses pengambilan keputusan, koordinasi, dan pengendalian sedangkan pariwisata dapat diartikan sebagai suatu kegiatan manusia yang melakukan perjalanan ke suatu daerah dan tinggal di daerah tujuan di luar lingkungan kesehariannya dalam jangka waktu tertentu untuk tujuan bersenangsenang atau bisnis.

Dari dua pengertian tersebut dapat diartikan bahwa sistem informasi pariwisata adalah sekumpulan komponen yang saling bekerjasama untuk mengumpulkan, memproses, menyimpan dan mendistribusikan data yang berhubungan dengan hasil kebudayaan, tata cara hidup suatu masyarakat serta kekhasan alam yang dimiliki daerah tertentu yang berbeda dengan lingkungan keseharian.

\subsubsection{Pengertian Pariwisata}

Menurut etimologi kata, Pariwisata berasal dari dua suku kata bahasa Sansekerta, "pari" yang berarti banyak atau berkali-kali dan "wisata" yang berarti perjalanan atau bepergian. Jadi, pariwisata diartikan sebagai suatu perjalanan yang dilakukan berkali-kali. Secara umum pariwisata merupakan suatu perjalanan yang dilakukan seseorang untuk sementara waktu yang diselenggarakan dari suatu tempat ke tempat yang lain dengan meninggalkan tempat semula dan dengan suatu perencanaan atau bukan maksud untuk mencari nafkah di tempat yang dikunjunginya, tetapi semata-mata untuk menikmati kegiatan pertamasyaan atau rekreasi untuk memenuhi keinginan yang beraneka ragam.

Menurut Cooper dalam Heriawan (2004) pariwisata adalah serangkaian kegiatan perjalanan yang dilakukan oleh perorangan atau keluarga atau kelompok dari tempat tinggal asalnya ke berbagai tempat lain dengan tujuan melakukan kunjungan wisata dan bukan untuk bekerja atau mencari penghasilan di tempat tujuan. Kunjungan yang dimaksud bersifat sementara dan pada waktunya akan kembali ke tempat tinggal semula. Hal tersebut memiliki dua elemen yang penting, yaitu: perjalanan itu sendiri dan tinggal sementara di tempat tujuan dengan berbagai aktivitas wisatanya. Heriawan (2004) mengomentari uraian tersebut memiliki pengertian bahwa tidak semua orang yang melakukan perjalanan dari suatu tempat (tempat asal) ke tempat lain termasuk kegiatan wisata. Perjalanan rutin seseorang ke tempat bekerja walaupun mungkin cukup jauh dari segi jarak tentu bukan termasuk kategori wisatawan.

\subsection{Metode Penelitian}

Metode penelitian merupakan cara ilmiah yang digunakan untuk melakukan suatu penelitian. Metode yang digunakan dalam penelitian ini adalah Deskriptif. Menurut Azwan (2004:7) penelitian deskriptif adalah melakukan analisis hanya sampai pada tahap deskripsi, yaitu menganalisis dan menyajikan fakta secara sistematik sehingga dapat lebih mudah disimpulkan.

Metodologi penelitian adalah langkah-langkah sistematik yang digunakan untuk mengejakan atau menyelesaikan suatu masalah. Metode penelitian digunakan sebagai pedoman dalam melaksanakan penelitian agar hasil yang dicapai tidak menyimpang dari tujuan yang ditentukan sebelumnya. Adapun metode penelitian yang dilakukan penulis dalam merancang sistem informasi objek wisata berbasis web di kabupaten Simalungun adalah sebagai berikut :

1. Metode Pengumpulan Data

a. Observasi. Penulis mengambil data melalui pengamatan ke lokasi wisata. 
b. Kuesioner. Penulis mengumpulkan data dengan cara memberikan daftar pertanyaan (kuesioner) untuk diisi oleh responden.

2. Metode Analisa

Dalam metode ini penulis mengolah data yang telah didapat menjadi informasi, sehingga sifat-sifat data dapat dengan mudah dipahami dan bermanfaat bagi penulis dalam menyelesaikan masalah yang berkaitan dengan penelitian.

3. Metode Perancangan

Dalam metode ini penulis merancang prototipe sistem dari data yang telah diolah menjadi informasi sehingga memberi gambaran yang jelas dan rancangan prototipe sistem yang lengkap bagi penulis.

Pada penelitian ini, penulis menggunakan data untuk membantu memecahkan masalah yaitu: (1) Data primer adalah data yang diperoleh secara langsung dari wisatawan dengan melakukan observasi dan kuesioner, (2) Data sekunder adalah data yang diperoleh melalui studi kepustakaan dengan mempelajari berbagai tulisan melalui buku, jurnal, majalah dan juga internet untuk mendukung penelitian ini.

\subsection{Hasil dan Pembahasan}

\subsubsection{Perancangan Sistem}

Membuat suatu situs memerlukan persiapan, perencanaan yang baik, tujuan yang jelas dan percobaan yang berulangulang karena menyangkut semua elemen yang membentuk situs. Rancangan sistem adalah penentuan proses dan data yang diperlukan oleh sistem baru. Tujuan dari perancangan sistem adalah untuk memenuhi kebutuhan user mengenai gambaran yang jelas tentang perancangan sistem yang akan dibuat serta diimplementasikan. Rancangan program ini dapat digambarkan dengan menggunakan flowchart (diagram alir).

\subsubsection{Data Flow Diagram (DFD)}

$$
\text { Data Flow Diagram (DFD) }
$$

merupakan model dari sistem untuk menggambarkan pembagian sistem ke modul yang lebih kecil. Salah satu keuntungan menggunakan diagram alir data adalah memudahkan pemakai yang kurang menguasai bidang computer untuk mengerti sistem yang akan dikerjakan. Pada tahap analisa, penanganan notasi simbol lingkaran dan anak panah menggambarkan arus data dalam perancangan sistem sangat membantu dalam komunikasi dengan pemakaian sistem menggunakan notasi - notasi untuk menggambarkan arus dari data sistem.

Disamping itu DFD adalah salah satu alat pembuatan model yang sering digunakan, khususnya bila fungsi-fungsi sistem merupakan bagian yang lebih penting dan kompleks dari pada data yang dimanipulasi oleh sistem. Dengan kata lain, DFD adalah alat pembuatan model yang memberikan penekanan hanya pada fungsi sistem. DFD memiliki simbol-simbol yang digunakan untuk menggambarkan model data seperti yang tertera pada gambar berikut ini :

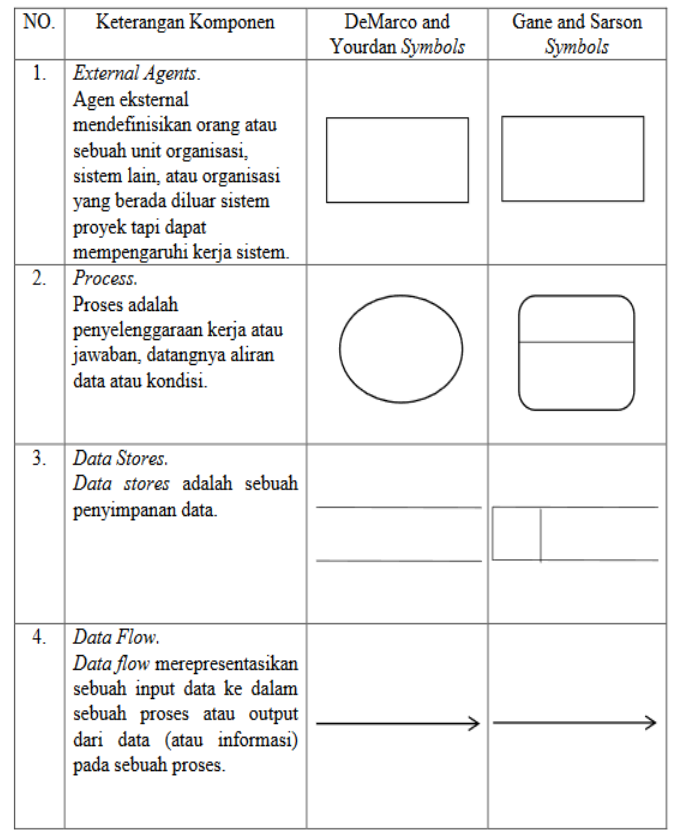

Gambar 1. Komponen-Komponen DFD Sumber : (Indrajani, 2011)

Adapun Data Flow Diagram (DFD) yang penulis ajukan dalam perencanaan prototipe sistem informasi pariwisata di Kabupaten Dairi yaitu: 


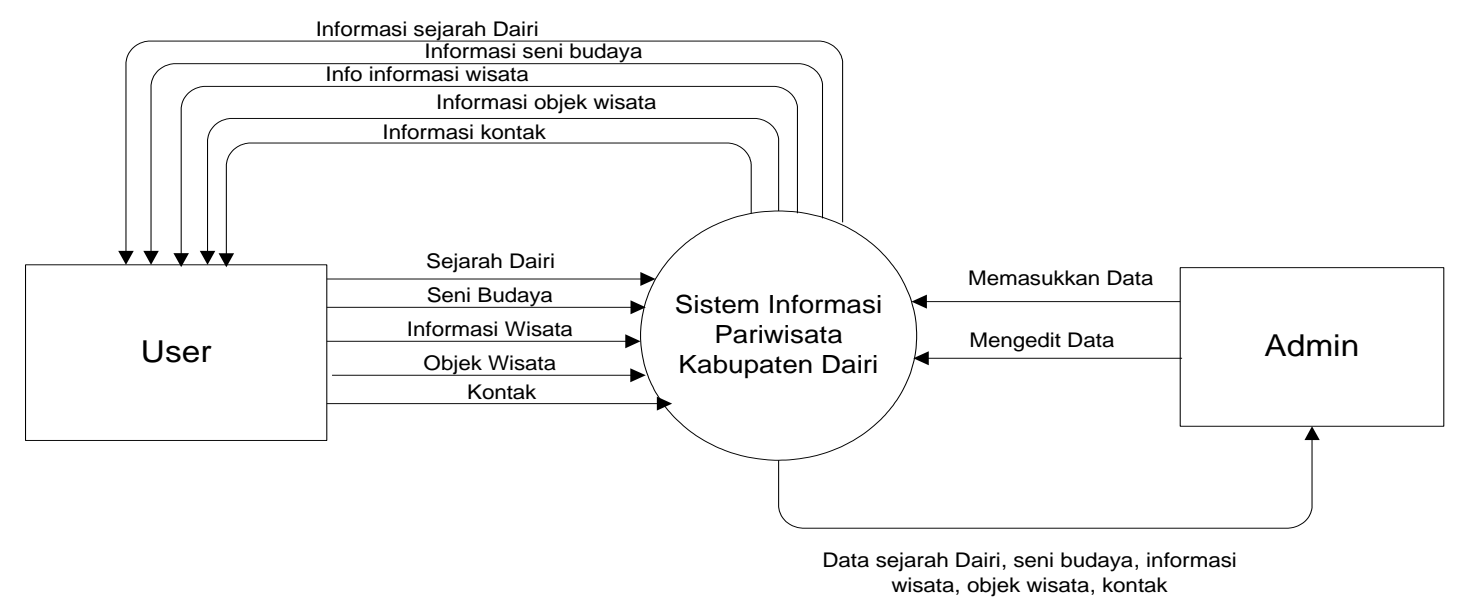

\subsubsection{Flowchart}

Flowchart adalah sekumpulan symbol-simbol yang menunjukan atau menggambarkan rangkaian kegiatankegitan program dari awal hingga akhir. Jadi flowchart juga dapat digunakan untuk menggambarkan urutan langkah-langkah pekerjaan dalam suatu algoritma.

Penjelasan arti dari lambinglambang flowchart dapat didefinisikan seperti terlihat pada Tabel 1, adalah:

Tabel 1. Lambang Flowchart

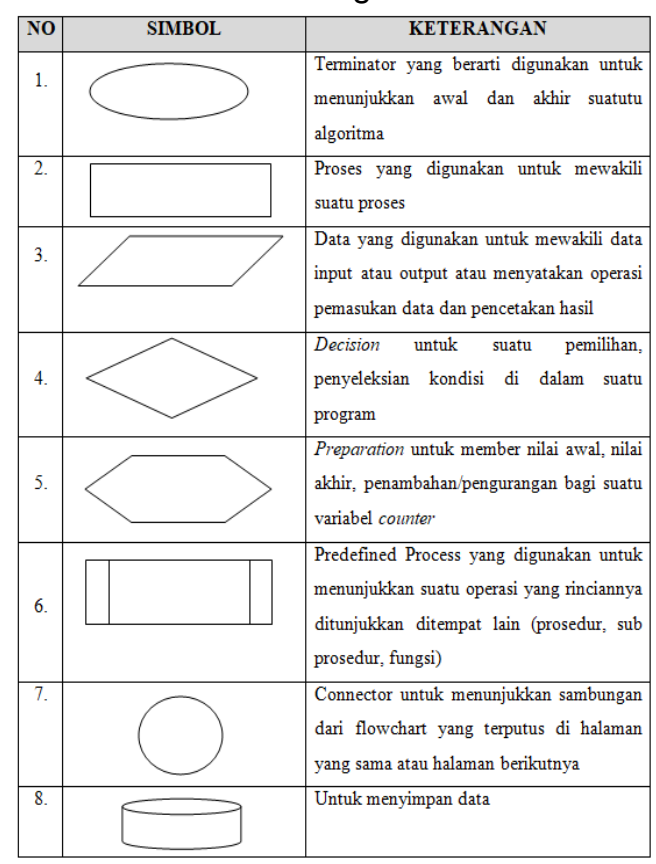

Sumber : Sumber : (Indrajani, 2011)

1. Flowchart Menu Utama

Flowchart menu utama dapat dilihat pada gambar berikut : sejarah Dairi, seni budaya, informasi
wisata, objek wisata, kontak

Gambar 2. DFD SIP Kabupaten Dairi

Sumber : (Olahan Data Penulis, 2018)

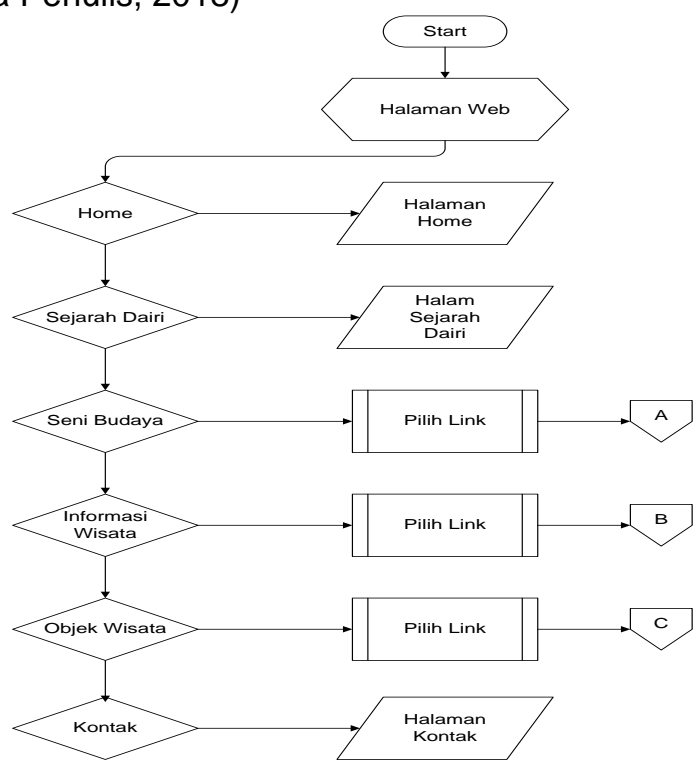

Gambar 3. Flowchart Menu Utama

Sumber : (Olahan Data Penulis, 2018)

2. Flowchart Menu Seni Budaya

Flowchart menu seni budaya dapat

dilihat pada gambar berikut :

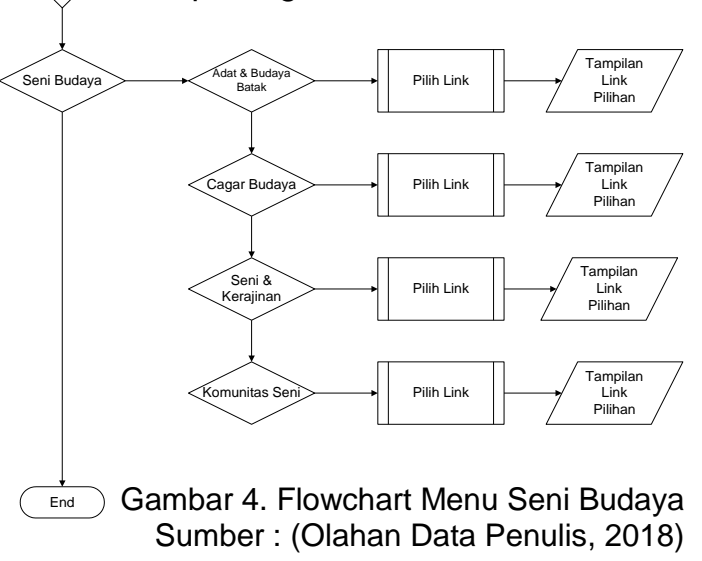




\section{Flowchart Menu Informasi Wisata} Flowchart menu informasi wisata dapat dilihat pada gambar berikut :

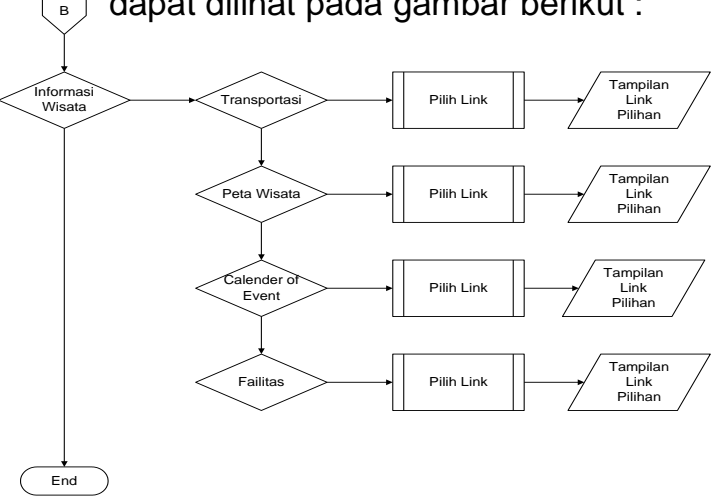

Gambar 5. Flowchart Menu Informasi Wisata Sumber: (Olahan Data Penulis, 2018)

4. Flowchart Menu Objek Wisata Flowchart menu objek wisata dapat dilihat pada gambar berikut :

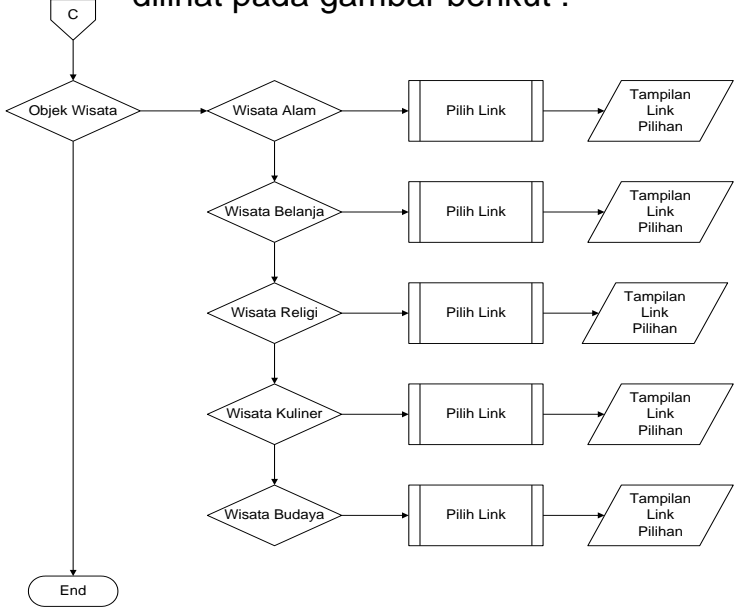

Gambar 6. Flowchart Menu Objek Wisata Sumber : (Olahan Data Penulis, 2018)

5. Flowchart Menu Admin Flowchart menu admin dapat dilihat pada gambar berikut :

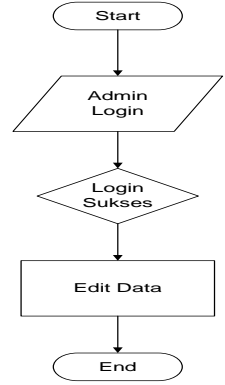

Gambar 7. Flowchart Menu Admin

Sumber : (Olahan Data Penulis, 2018)

\subsubsection{Perancangan Database}

Database adalah kumpulan dari data yang berhubungan antara yang satu dengan yang lainnya, tersimpan diperangkat keras komputer dan menggunakan perangkat lunak untuk memanipulasinya. Database merupakan salah satu komponen yang penting dalam sistem informasi, karena database merupakan kumpulan dari beberapa file, dalam hal ini file-file tersebut dikelompokkan secara terstruktur dalam beberapa tabel sesuai dengan informasi yang terkandung didalamnya.

Berikut rancangan tabel yang penulis gunakan dalam membangun sistem :

1. Tabel Admin

Tabel 2. Tabel Admin

\begin{tabular}{|l|c|c|c|}
\hline \multicolumn{1}{|c|}{ Nama Field } & $\begin{array}{c}\text { Tipe } \\
\text { Data }\end{array}$ & Ukuran & $\begin{array}{c}\text { Primary } \\
\text { Key }\end{array}$ \\
\hline id_admin & Integer & 5 & Yes \\
\hline username_admin & Varchar & 50 & \\
\hline password_admin & Varchar & 50 & \\
\hline
\end{tabular}

Sumber : (Olahan Data Penulis, 2018)

2. Tabel Menu

Tabel 3. Tabel Menu

\begin{tabular}{|l|c|c|c|}
\hline Nama Field & $\begin{array}{c}\text { Tipe } \\
\text { Data }\end{array}$ & Ukuran & $\begin{array}{c}\text { Primary } \\
\text { Key }\end{array}$ \\
\hline id_menu & Integer & 10 & Yes \\
\hline nama_menu & Varchar & 100 & \\
\hline menu & Varchar & 100 & \\
\hline
\end{tabular}

Sumber : (Olahan Data Penulis, 2018)

3. Tabel Sub Menu

Tabel 4. Tabel Sub Menu

\begin{tabular}{|l|c|c|c|}
\hline Nama Field & $\begin{array}{c}\text { Tipe } \\
\text { Data }\end{array}$ & Ukuran & $\begin{array}{c}\text { Primary } \\
\text { Key }\end{array}$ \\
\hline id_submenu & Integer & 10 & Yes \\
\hline id_menu & Varchar & 100 & \\
\hline nama_sub & Varchar & 100 & \\
\hline
\end{tabular}

Sumber : (Olahan Data Penulis, 2018)

4. Tabel Konten

Tabel 5. Tabel Admin

\begin{tabular}{|l|c|c|c|}
\hline Nama Field & $\begin{array}{c}\text { Tipe } \\
\text { Data }\end{array}$ & Ukuran & $\begin{array}{c}\text { Primary } \\
\text { Key }\end{array}$ \\
\hline id & Integer & 10 & Yes \\
\hline id_menu & Integer & 10 & \\
\hline id_submenu & Integer & 10 & \\
\hline nama & Varchar & 100 & \\
\hline deskripsi & Text & & \\
\hline gambar & Text & & \\
\hline
\end{tabular}

Sumber : (Olahan Data Penulis, 2018)

\subsubsection{Perancangan Output}

Perancangan sistem merupakan kegiatan yang dilakukan setelah diselesaikannya proses sistem. Salah satu faktor agar situs diminati para pengunjung adalah desain

layout yang bagus. Berikut desain layout yang dibuat, diantaranya adalah: 
1. Bagian header berisi nama informasi web dan beberapa grafik untuk mempercantik tampilan.

2. Bagian navigasi (Home, Sejarah Dairi, Seni Budaya, Informasi Wisata, Objek Wisata, Kontak) merupakan pilihan menu bagi pengguna yang harus dikenali dan mudah digunakan.

3. Bagian content merupakan isi yang ingin disampaikan pada pengunjung.

4. Bagian footer berisi nama dan info dari pemilik situs.

5. Bagian-bagian lainnya, bisa merupakan artikel, info terkini, kategori, banner, waktu dan tanggal.

Tujuan dari rancangan output adalah mengubah data menjadi informasi yang berkualitas dan dapat digunakan sebagai dasar pengambilan keputusan yang tepat.

1. Perancangan Halaman Home

Halaman utama (Home) merupakan halaman depan dari semua halaman yang ada pada website. Halaman ini juga dapat disebut sebagai halaman pembuka karena pada saat pertama website dibuka. Pada halaman utama akan dirancang cukup kompleks karena akan ada link ke semua halaman lainnya. Rancangan halaman utama dapat dilihat pada gambar berikut :

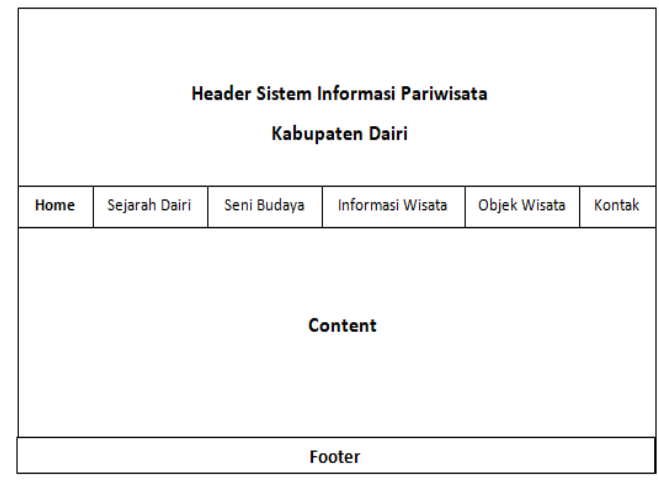

Gambar 8. Perancangan Halaman Home

Sumber : (Olahan Data Penulis, 2018)

2. Perancangan Halaman Sejarah Dairi Halaman Sejarah Dairi merupakan halaman yang berisi sejarah terbentuknya kabupaten Dairi. Rancangan halaman sejarah Dairi dapat dilihat pada gambar berikut :

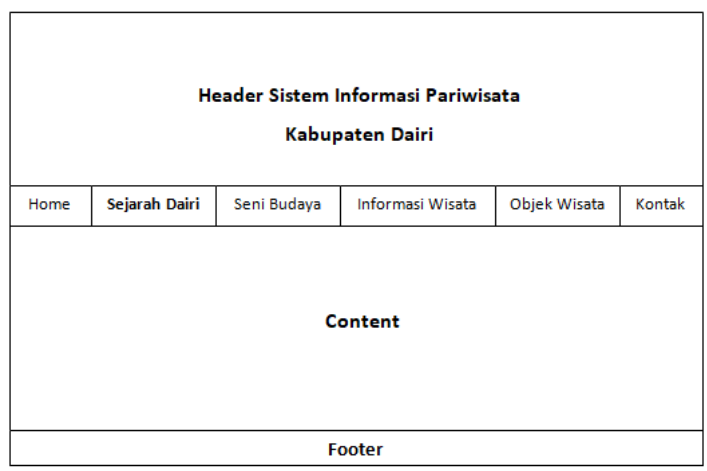

Gambar 9. Perancangan Halaman Sejarah Dairi

Sumber : (Olahan Data Penulis, 2018)

3. Perancangan Halaman Seni Budaya

Halaman Seni Budaya merupakan halaman yang berisi menu adat \& budaya batak, cagar budaya, seni \& kerajinan, komunitas seni yang ada di Kabupaten Dairi. Rancangan halaman seni budaya dapat dilihat pada gambar berikut:

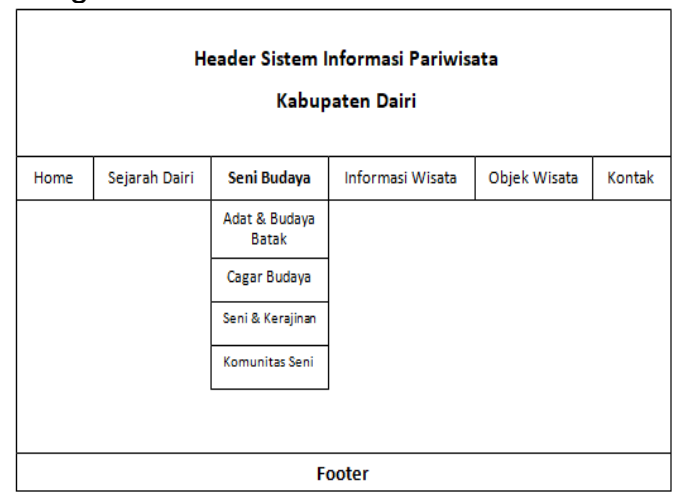

Gambar 10. Perancangan Halaman Seni Budaya

Sumber : (Olahan Data Penulis, 2018)

4. Perancangan Halaman Informasi Wisata

Halaman Informasi Wisata merupakan halaman yang berisi menu transportasi menuju ke objek-objek wisata di Dairi, peta wisata, calendar of event, fasilitas wisata di Kabupaten Dairi. Rancangan halaman informasi wisata dapat dilihat pada gambar berikut : 


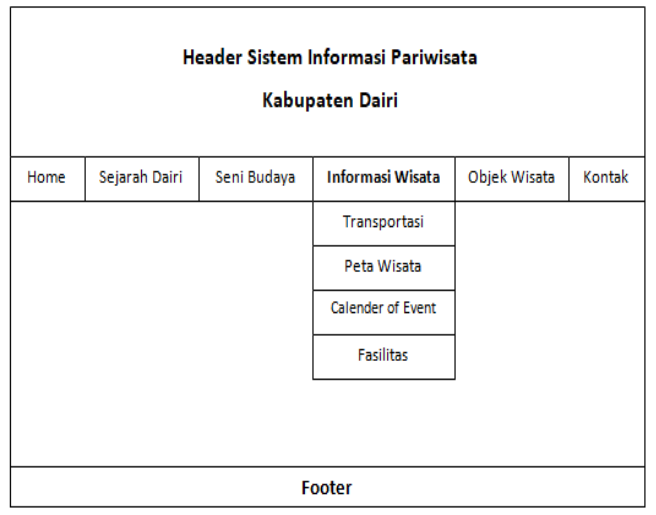

Gambar 11. Perancangan Halaman Informasi Wisata

Sumber : (Olahan Data Penulis, 2018)

5. Perancangan Halaman Objek Wisata

Halaman Objek Wisata merupakan halaman yang berisi menu wisata alam, wisata belanja, wisata religi, wisata kuliner, wisata budaya yang ada di Kabupaten Dairi. Rancangan halaman objek wisata dapat dilihat pada gambar berikut :

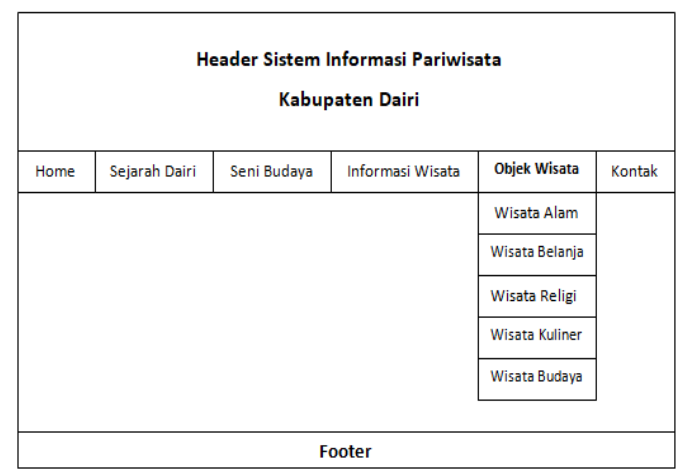

Gambar 12. Perancangan Halaman Objek Wisata Sumber : (Olahan Data Penulis, 2018)

6. Perancangan Halaman Kontak Halaman Kontak merupakan halaman yang berisi kontak dari pengolah situs web. Rancangan halaman kontak dapat dilihat pada gambar berikut :

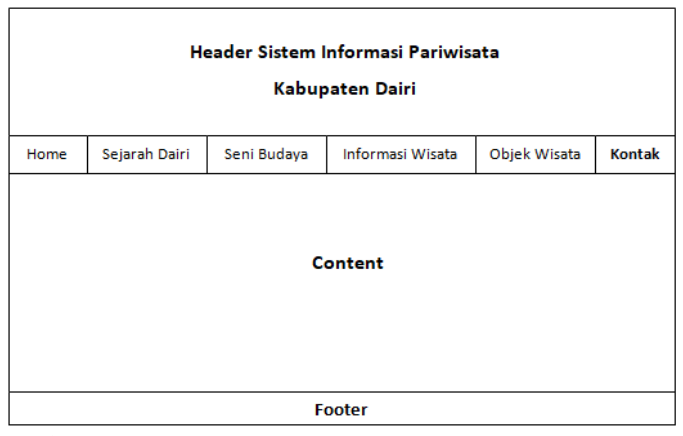

Gambar 13. Perancangan Halaman Kontak
Sumber : (Olahan Data Penulis, 2018)

7. Perancangan Halaman Admin

Halaman Admin merupakan halaman untuk memantau, mengisi dan mengupdate berita, data wisata, data hotel, komentar dan berita dari semua halaman yang ada pada website. Halaman ini juga dapat disebut sebagai halaman pemilik website

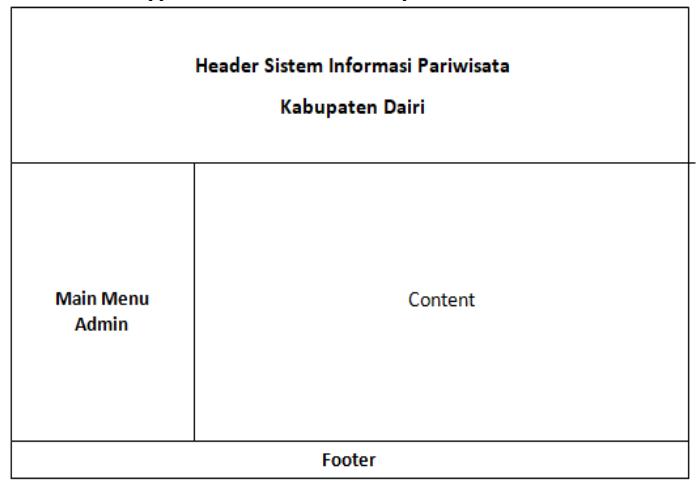

Gambar 14. Perancangan Halaman Admin Sumber : (Olahan Data Penulis, 2018)

\subsection{Kesimpulan}

Dari uraian yang telah dipaparkan dalam perencanaan prototipe sistem informasi pariwisata di kabupaten Dairi dapat dibuat kesimpulan sebagai berikut :
1. Sistem Informasi Pariwisata
Kabupaten Dairi dapat membantu mempromosikan Pariwisata Kabupaten Dairi kepada seluruh masyarakat di Tanah air Indonesia bahkan masyarakat internasional.

2. Sistem Informasi Pariwisata Kabupaten Dairi memberikan kemudahan kepada masyarakat dalam mencari informasi mengenai pariwisata, sejarah Dairi, seni budaya setempat.

3. Sistem Informasi Pariwisata Kabupaten Dairi memberikan kemudahan dalam menginformasikan berita tentang pariwisata dan perkembangan kepariwistaan Kabupaten Dairi.

4. Dengan adanya sistem informasi berbasis web, penyampaian informasi pariwisata jauh lebih efektif dibandingkan sistem manual.

\subsection{Saran}

Berdasarkan kesimpulan yang telah diperoleh dari hasil penelitian ini, maka 
peneliti menyarankan beberapa saran diantaranya sebagai berikut :

1. Diharapkan nantinya sistem ini dibuat dalam bentuk sistem berbasis android dikarenakan sudah maraknya penggunaan smartphone dalam masyarakat luas.

2. Dalam pengembangan sistem selanjutnya, diharapkan adanya transaksi online dalam sistem ini. Hal ini berkaitan dengan booking hotel dan booking tiket masuk ke suatu tempat pariwisata.

3. Pembangunan website masih bisa dibuat semenarik mungkin dan dikembangkan lebih lanjut terutama dalam tampilan sistemnya.

4. Dari segi yang disajikan mungkin belum sepenuhnya sempurna, oleh karena itu, ada baiknya dengan menambah beberapa informasi yang lebih lengkap.

5. Diharapkan pengolah sistem informasi pariwisata di Kabupaten Dairi nantinya terus memelihara dan memperbaharui data dan informasi sehingga masyarakat serta wisatawan memperoleh info yang terupdate.

\section{Daftar Pustaka}

[1] Azwan, Saifudin. (2004). Metode Penelitian. Pustaka Pelajar : Yogyakarta.

[2] Heriawan, Rusman. (2004). Peranan dan Dampak Pariwisata Pada Perekonomian Indonesia : Suatu Pendekatan Model I-O dan SAM. Disertasi. Doktoral Institut Pertanian Bogor. Bogor.

[3] Indrajani. (2011). Perancangan Basis Data dalam All in 1, PT. Elex Media Komputindo : Jakarta.

[4] Mulyanto. Agus. (2010). "Sistem Informasi Konsep \& Aplikasi”. Pustaka Pelajar : Yogyakarta.

[5] Mustakini, Jogiyanto Hartono. (2010). Sistem Informasi Teknologi. Andi Offset : Yogyakarta.

[6] Nazir, Moh. (2003). Metode penelitian. Ghalia Indonesia, Jakarta.

[7] Nawawi, Hadari, (2001). Metode Penelitian Bidang Sosial. Yogyakarta: Gajah Mada University Press

[8] Nugroho, Bondan Dwi, dan Imam Azhari. Sistem Informasi Inventori FADEGORETAS!! TM Berbasis Barcode. Yogyakarta: Universitas Ahmad Dahlan. Vol. 1, No. 2, September 2011.

[9] Sutabri. Tata. (2012). Konsep Sistem Informasi. Andi Offset : Yogyakarta. 